\title{
ESKİ TÜRKLERDE ASKERİ YAPI *
}

\author{
Military Structure in Ancient Turks
}

Eda DURMUŞ **

$\ddot{o} z$

Bozkırlar Orta Asya, Kuzey Asya ve Doğu Avrupa olarak bilinen cŏgrafi sahadan oluşmaktadır. Bu coğrafyada uzun zaman diliminde varlıklarını hissettirmişler ve kendilerine ait bir kültür oluşturmuşlardır. Onlar atı ehlileştirip, binek hayvanı olarak kullanmışlardır. Bundan başka maden işleyiciliği, özellikle demircilikte ileri gitmişlerdir. Atın hızı ve demirin vurucu gücünden büyük ölçüde yararlanmışlardır. Onların kültürleri at ve demir sayesinde güç ve hız kazanmıştır. Askeri yönden güçlü bir yapıya kavuşmuşlardır. Hem kurgan buluntuları hem de yazll kaynaklardaki bilgiler onların askeri gücünü açık bir şekilde ortaya koymaktadır. Onların yetiştiği çevre ve eğitimleri askeri bakımdan güçlerini ortaya koymaktadır. Askeri kavram ve unvanlar da oldukça önemliydi. Unvanlar arasında arslan, kaplan ve kurt gibi yırtıcı hayvan adları bulunuyordu. Yırtıcı kuşlardan kartal, doğan ve şahin adı da unvan olarak kullanılıyordu. Bozkır kavimlerinin orduları düzenli bir yapıya sahipti. Ordu birlikleri Onlu sisteme göre oluşturulmuştu. Ordu içinde süvari, yaya, özel ve keşif birlikleri vardı. Ordunun asıl ana unsurunu süvari birlikleri oluşturuyordu. Süvariler savaşlarda at üzerinde en çok yay gerip ok atıyordu. Bu durumda uzaktan savaş taktiğini uygulamaktaydılar. Böyle bir savaş kendileri için kan kaybını azaltıyordu.

Anahtar Kelimeler: Türk, süvari, at, demir, unvan, birlikler.

\section{Abstract}

Steppes consist of geographical places which are known as Central Asia, North Asia and Easteren Europe.The Steppe tribes made their presence felt in this geography for a long time and created a culture of their own. They tamed the horse and used it as a riding horse. Moreover, they have gone further in mining, especialy in forging. They greatly benefited from the speed of the horse and the striking power of iron. Their cultures gained strength and speed thanks to horse and iron. They have reached a strong military structure. Both kurgan finds and information in written sources clearly demonstrate their military power. Their environment which they grow into and the education they got, reveals their superior military power. Military concepts and titles were also very important. Titles included predator names such as lion, tiger and wolf. The names of the eagle, born and hawk, which is the birds of hunter, were also used as titles. Armies of steppe tribes had a regular structure. Army troops were formed according to the decimal system. There were cavalry, pedestrian, private and reconnaissance troops within the army. Cavalry troops were the main element of the army. Cavalry were stretching bow and throwing arrows while standing on their horses in the war area. In this case, they were implementing remote combat tactics. Such a war was reducing blood loss for them.

Key Words: Turks, cavalry, horse, iron, title, troops.

\section{Giriş}

Türklerin askeri yapıları bozkırlarda oluşup geliş̧miştir. Bozkır "kurakçıl otsu bitkilerden oluşan, sıcak ve 1lıman iklimlerde geniş alanlara yayılan, ağaçsız doğal bölge, step” şeklinde açıklanmaktadır (Eren, vd., 1988: 218). Step kelimesi bozkır anlamında kullanılmıştır (Mustafayev, vd., 1989: 877). Buradan "step" kelimesinin "ot", "çimen" anlamında kullanıldığı ve çayırlık alanları ifade ettiği anlaşılmaktadır. Bu kelime ilk kez Rusçada görülmekle birlikte, diğer dünya dillerine de geçerek aynen kullanılmıştır. Türkçeye de girmiş olan kelime, Türkçede "istep" şeklinde kullanılmıştır. Sonradan "boz" ve "kır" kelimelerinin bir araya gelmesinden oluşan "bozkır", "istep", yani "step" kelimesinin yerine kullanılmaya başlamıştır.

\footnotetext{
${ }^{*}$ DOI: 10.34189/asyam.4.1.007

** Ankara Hacı Bayram Veli Üniversitesi Lisansüstü Eğitim Enstitüsü, eda.durmus@ @bv.edu.tr
} 
Bozkırlardan anlaşılması gereken "Eurasia" olarak bilinen "Avrasya" ve "Avrasya Bozkırları"dır (Steuerwald, 1988: 205). Coğrafi olarak Eurasia, Avrupa'nın doğu, Asya'nın orta ve kuzey kesimlerini kaplayan, iki kıta arasında adeta üçüncü bir kıta oluşturan çok geniş bir sahadır. (Rasonyi, 1993: 1). Bu bağlamda Orta Asya, Kuzey Asya ve Doğu Avrupa bozkırları oluşturmaktadır.

Bozkırlarda tarih öncesi dönemlerden başlamak üzere önemli tarihi gelişmeler olmuştur. Büyük Bozkır Türk devletleri bu coğrafya üzerinde kurulmuştur. Kronolojik olarak 1. Proto Türkler, 2. İskit/Saka Devleti, 3. Büyük Hun Devleti, 4. Gök Türk Devleti ön plana çıkmaktadır. Proto Türk dönemi için Anav, Afanesyovo, Kelteminar, Andronovo, Karasuk, Tagar ve Taştık kültürleri dikkati çekmektedir. İskit/Saka Devleti (M.Ö. 8. Yüzy1l- M.Ö. 2. Yüzy1l), Büyük Hun Devleti (M.Ö. 318- M.S. 216), Avrupa Hun Devleti (350- 469), Gök Türk Devleti (552- 744) şeklinde sıralanmaktadır (Koca, 2002: 260- 265). Bu kronolojik siralama Türklerin askeri yapısının oluşumu ve gelişimine etki etmiştir.

Bozkırlarda birçok kayda değer gelişme "Proto Türk Dönemi" olarak kabul edilen dönemde ortaya çıkmıştır. Arkeolojik buluntulardan hareketle Türk kültür safhaları ve bu kültürün gelişimi takip edilebilmektedir. Başlangıçta taştan ve kemikten yapılmış buluntular görülürken, sonra bakırdan buluntular dikkati çekmektedir. İnsanlık tarihinde görülen gelişmelere bakıldığında; taş devri ve onu takip eden maden devri dikkati çekmektedir. Bakırın kullanılmaya başlamasıyla bakır devri, bakırla kalayın alaştırılmasıyla elde edilen tuncun kullanımıyla tunç devri, demirin kullanılmaya başlamasıyla demir devri ya da demir çağı tabirlerinin kullanıldığı görülmektedir. Şüphesiz demirin kullanılmaya başlamasıyla yeni bir dönemin başladığı söylenebilir (Koca, 1990: 14- 16).

Atın ehlileştirilmesi ve atlı kültürün ortaya çıkışı doğrudan Türklerle bağlantılıdır. İnsanlık tarihinde ulaşılan bu başarı, kavimlerin ve diğer kültürlerin gelişmesinde önemli sonuçlar doğurmuştur. Tarihi bağlantıların gösterdiği gibi, büyük devlet esası için gerekli şartlar ancak bu sayede belirebilmiştir (Koppers, 1941: 471). Atlı kültürün Türk kültür çevresinde ortaya çıkışını büyük ölçüde arkeolojik kazılar sonucunda ortaya çıkarılmış buluntulardan da anlamak mümkündür. Bozkırlarda görülen bir dizi yeni gelişmeler arasında ata binme ve tekerlekli arabaların kullanımı önemli bir yer tutmaktadır. Binek ve koşum atlarının en erken örnekleri Balhan mezarları kültürü ve Andronovo kültürü gömülerinde ortaya çıkmıştır. Bu dönem buluntu merkezlerinde at kalıntıları önemli bir yer tutmaktadır. Karasuk mezarlarında da at ortaya çıkarılmışır (Zvelebil, 1980: 253). Şüphesiz Türk kültür çevresinde atın binek hayvanı olarak kullanılması ön plana çıkmaktadır. Çünkü ata binilmesi, atın arabaya koşulmasından daha ileri bir gelişmedir. Türkler bu sayede süvari olarak varlıklarını sürdürmüş, askeri güç kazanmış ve büyük devlet kurabilecek şartları oluşturmuşlardır.

Bozkır kültürü özü itibariyle diğer göçebe kültürlerinden farklılık göstermektedir. Çünkü çöl göçebeleriyle bozkırlıların hayat tarzları birbirinden farklılık göstermektedir. Çöl göçebeliğinin ana unsuru devedir. Bozkır konar- göçerliğinin ana unsuru ise attır. At bu kültüre canlılık kazandırmış olup, adı geçen kültür "kuvvet, hareket ve sürat" üzerine kurulmuştur (Koca, 2010: 14). Türkler, atın hızı ve demirin vurucu gücü sayesinde, geniş coğrafyalara yayılmış ve oralarda hâkimiyet kurabilmişlerdir.

Bozkırlarda, konar- göçer külttürün en yüksek derecesi olan "atlı kültür” gelişmiştir. Dünya tarihinde önemli yeri olan Türk devletleri, bozkır coğrafyası üzerinde ortaya çıkmıştır. Ural ve Altay Dağları arasında uzanan bozkır bölgesi, büyük atlı kültür dairesinin merkezi olmuş, hayvan besleyen atlı bozkırlıların uygarlığı buradan çevreye yayılmıştır. Bu çevrede, at besleme kültürü doğmuştur. At besleyiciliği, bozkırlarda bütün hayatın temelini oluşturmuş, yalnız yük taşımakta değil, avcılık ve beslenme konusunda da ondan çok yararlanılmıştır (Arslan, 1984: 1- 2).

Atın kullanımının yanında demir de önemli bir yer tutmaktadır. Demir, insanlık tarihinde kullanılmaya başlamasıyla birlikte önemli bir yer tutmuştur. Onun bu önemi, kültürel süreklilik içersinde hep süregelmiştir. Demir, bozkır kültür çevresinde sosyal, siyasi, iktisadi, askeri ve dini hayat ile sanat anlayışında birinci derecede önem taşıyan bir maden olma özelliğini korumuştur. Bu durum, demirin bozkır kültürüne dinamizm ve güç kazandırdığını göstermektedir. "Mavimtrak esmer renkte olan demir 1510 C'de eriyen bir element" (Eren, vd., 1988: 352) olduğundan eritilmesi için çok yüksek ateşe ihtiyaç duyulmaktadır. Kullanımı da diğer kültür coğrafyalarında da olduğu gibi, diğer madenlerin kullanımından daha sonra olmuştur.

Türklerin diğer toplumların üzerinde kolayca siyasi egemenlik kurmalarını demir madeni sağlıyordu. Onların fetih hareketlerinde asıl rol oynayan maden, daha önceki çağlarda da bilinen bakır, tunç ve altın değil, demir idi. Demir farklı kültür coğrafyalarında bilinse de, gerçek demir çağı bu madenden bol miktarda alet ve 
silah yapımıyla başlamıştır. Bu imkân da büyük ölçüde Altaylarda, Yenisey nehrinin kaynak bölgelerinde mevcut olmuştur. Altaylılar, bilindiği üzere, çok eskiden beri mahir demirciler olarak tanınmışlardır. Tarihi devirlerde de aynı bölgede yüksek kalitede demir cevherine rastlanılmış, Kuzey Altaylarda demir eritme ocakları, Baykal'ın doğusunda demir ocak ve döküm yerleri ortaya çıkarılmıştır (Kafesoğlu, 1989: 211- 212). Çin kaynaklarına göre, Yenisey'in yukarı yatağı dolaylarında eskiden beri demir filizi toplanıyordu. Abakan havalisinde yüksek vasıfta mıknatıs ve Tuba ırmağı boyunca demir cevheri bulunuyordu. İnsanlık tarihinde bir çağın açılmasına başlangıç oluşturacak miktarda demir madeninin varlığı eski Türk yurdunda fark edilmiş ve işlenmeğe geçilmişti (Kafesoğlu, 1989: 212).

Bozkır kültür çevresinde, özellikle Altayların batısında demir, aşağı yukarı M.Ö. 1400'lerde önemli miktarda elde edilmiştir. Bu durum, bozkır kültür sahasının tarihi belgelerden hareketle demir kültürünün doğduğu saha olduğunu göstermektedir (Ruben, 1943: 240). Kurganlardan elde edilen malzemeden demir işleyiciliğinin Orta Asya'daki kesin tarihi belirlenememiş olup, M.Ö. 2. bin başlarına rastladığı belirtilmiştir. Türklerin daha o asırlarda geniş sahalara hükmedebilmeleri, sürat bakımından atın sağladığı üstünlük yanında, vurucu silah olarak demir alet ve vasıtalarını geniş ölçüde kullanılmış olması ile açıklanmaya çalışılmıştır (Kafesoğlu, 1989: 212). Türkistan'da demir kültürünün M.Ö. 2000’lerde varlığına dikkat çekilerek, yukarıda belirtilen görüş desteklenmiştir. Ayrıca demirin bozkır kültür çevresinde M.Ö. 1022 yılına ait Çin kayıtlarında varlığına da dikkat çekilmiştir. Bu kayıtta "lüks kılıç" anlamında "king-luk" kelimesi Türkçede "ikiyüzlü bıçak" anlamında günümüzde dahi kullanılan "kingirlik" kelimesiyle özdeşleştirilmiştir (Togan, 1981: 30). Bütün bu verilerden hareketle bozkır kültür çevresinde aşağı yukarı M.Ö. 1200’lerde demir kullanımı yaygınlık göstermiş ve demirden savaş gereçleri yapılmaya başlanılmıştır.

Türklerin teşkilatlanabilmeleri ve bozkırlarda güçlü devletler kurabilmeleri yaşadıkları kültür coğrafyasının tarih öncesi devirlerine kadar gitmektedir. Çin belgelerinde Tuman zamanına kadar Hun devletiyle ilgili şu bilgi dikkate değerdir: "1000 yıldan daha uzun zaman sürecinde devlette zaman zaman büyüme, zaman zaman küçülme oldu, fakat bölündüler, parçalandılar” (De Groot, 1921: I, 53). Bu bölünüp parçalanma zaman zaman devletin küçülmesiyle ilgili olmalıdır. Çünkü 1000 yıldan fazla zaman sürecinde birleşip büyüdükleri, parçalanıp dağıldıkları ve yeniden birleşip büyüdükleri anlaşılmaktadır (Ögel, 1981: I, 121). Türk devletleri boyların bir araya getirilmeleri sonucu oluştuğundan boyların merkezi bir otorite etrafinda toplanması büyümeye, otoritenin ortadan kalkması ise küçülmeye neden olmaktaydı.

Güçlü Türk devletlerinin ortaya çıkması ve teşkilatlı devletin kurulabilmesi, boyların bir araya getirilerek bir devlet çatısı altında birleştirilmesi ile olabiliyordu. Tuman zamanından, yani aşağı yukarı M.Ö 200'lü yıllardan 1000 yıl eskiye gidildiğinde M.Ö. 1200'lere ulaşılmaktadır. Bu tarih arkeolojik boyutu ile atın binek hayvanı olarak kullanılmasının yanında demirin de yoğun olarak kullanımının yaygınlaşmaya başladığı zaman olarak bilinmektedir. Hatta "M.Ö. 1400'lerde Altayların batısı bol miktarda demirin üretildiği ve demir kültürünün doğduğu coğrafya olarak kabul edilmektedir (Kafesoğlu, 1989: 212).

Bozkır coğrafyasında teşkilatlı Türk devletlerinin ortaya çıkması M.Ö. 1200’lerde atın binek hayvanı olarak kullanımının yanında demirin de yoğun olarak kullanımı sayesinde olmuştur. Belirtilen tarihten sonra bozkırlarda sırasıyla İskitler, Asya ve Avrupa Hunları ile Gök Türkler siyasi varlıklarını sürdürmüşler. At ve demir sayesinde güçlü bozkır devletlerini kurup yaşatmışlardır. Bu durum onların askeri yapılarına açık bir şekilde yansımıştır. Bu tarihi süreçte Türk çevresinde askeri kavram ve unvanlar ile askeri teşkilat ve birlikler gelişim göstermiştir. Makalenin çerçevesi de bu belirtilenlerden oluşmaktadır.

\section{Askeri Kavram ve Unvanlar}

Eski Türklerin kültüründe askeri yapı çok önemli bir yer tutuyordu. Çünkü askerlik ve ordu düzeni en sistemleşmiş toplumlar onlardı. Bu bağlamda çok sayıda kavram kullanılıyordu. Bunlardan bir kısmı askeri teşkilatla ilgili bir kısmı ise teşkilat yapılanması dışındaki kavramlardı. Bunların bu denli çok Kavramın oluşu Türklerin hayatında askerlik ve ordunun önemini ortaya koymaktaydı.

En eski kavramlardan biri "sü” idi. Bu kelime "asker" karşılığında kullanılıyordu (Kaşgarlı Mahmud, 1992: IV, 547). Sü kelimesi aynı zamanda "ordu" anlamına da geliyordu (Donuk, 1988: 93). Çeriğ kelimesinin anlamı da "asker" idi (Kaşgarlı Mahmud, 1992: IV, 142). Urungu kelimesi ise, aynı şekilde "savaşçı" anlamına gelmekteydi (Donuk, 1988: 106). Bu kelimelerden askeri teşkilatı aydınlatacak kavramlar da üretilmişti. Bunlardan biri "Sü-başı= Sübaşı idi. Bu ise "ordu başı, ordu komutanı" anlamına geliyordu (Donuk, 1988: 93). Sü kelimesi ile birlikte bey kelimesi de kullanılmıştır. Bey boyun başında bulunan yönetici idi (Kafesoğlu, 
1989: 217). İdari yöneticiler, aynı zamanda askeri yöneticiler de olduklarından sü-beyi, "ordu başı” anlamına da geliyordu. Çerig başı da aynı anlamı taşıyordu (Koca, 2010: 99). Buradan başkomutan ve komutanların unvanları da ortaya çıkmaktadır.

Bozkır çevresinde uruş "savaş, mücadele" anlamına geliyordu (Caferoğlu, 1968). Aynı şekilde tütüş kelimesi de "savaş, harp, mücadele" anlamında kullanılıyordu (Caferoğlu, 1968: 260). Uruğ kelimesi ise "döğüş, vuruş" karş1lı̆̆nda kullanılıyordu (Kaşgarlı Mahmud, 1992: I, 27). Süngüş kavram olarak "savaş, muharebe, savaşta saldırma" olarak biliniyordu (Kaşgarlı Mahmud, 1992: III, 365). Yagıladaçı kelimesi de "mücahit, savaşkan, mücadeleci, savaşçı" anlamında idi (Caferoğlu, 1968: 279). Akınçı ise "akıncı, geceleyin düşmanı basan asker" anlamına geliyordu (Kaşgarlı Mahmud, 1992: IV, 16). Bası̆g ise "gece baskını yapılacak olan ve ansızın düşmanın yakalanacağı yer" anlamında kullanılıyordu (Kaşgarlı Mahmud, 1992: I, 372). Ilgar veya yılgar ise "baskın, hücum, akın, atlı hücum, dörtnala hücum" manasındaydı (Donuk, 1988: 98).

Yezek, yizek "asker öncüsü" anlamına geliyordu (Kaşgarlı Mahmud, 1992: III, 88). Yelme "izci, keşşaf, piştar, öncül” anlamında kullanılıyordu (Caferoğlu, 1968: 292). Yorçu "usta kılavuz" karşılığındaydı (Kaşgarlı Mahmud, 1992: III, 30). Yirçi ve yirtçi de kavram olarak "rehber, kılavuz, yer gösteren" anlamındaydı (Caferoğlu, 1968: 298- 299). Tıngçı "haberci” idi. Körüg kelimesi ise "casus" için kullanıllyordu (Caferoğlu, 1968: 117).

Yağı kavram olarak "düşman” karşı1lı̆ındaydı (Kaşgarlı Mahmud, 1992: IV, 726). Kır-yağı ise "gizli düşman" anlamına geliyordu (Kaşgarlı Mahmud, 1992: I, 364). Tutgun ve tutuğ "esir, tutsak, rehin" anlamlarında kullanılıyordu (Kaşgarlı Mahmud, 1992: IV, 662- 663). Tutkug "rehin" anlamındaydı (Caferoğlu, 1968: 255). Tutsak kelimesi de "rehin" anlamına geliyordu (Grönbech, 1992: 201).

Askeri teşkilat yapılanması içinde ele alacağımız gibi asker sayılarından hareketle oluşturulan birliklerin sayılarına göre de adlandırmalar mevcuttu. 10 bin kişilik bir birliğe "tümen" denildiğinden bu birliğin başında bulunan komutana "tümen başı" deniliyordu. Şüphesiz 1000, 100 ve 10 kişilik asker gruplarının başında bulunanların da hiyerarşik bir kademelenmeye göre unvanları mevcuttu.

Askeri unvanlardan biri de çabış, yani çavuş idi. Bu kavram için "savaşta safları düzelten, savaş olmadığı zaman da askeri zulmetmeye bırakmayan kimse" denilmektedir (Kaşgarlı Mahmud, 1992: I, 368). Bu bilgiden çavuşun önemli bir unvan olduğu anlaşılmaktadır. Çünkü ordunun savaş düzenine sokulması, safların karışmamasının sağlaması bakımından ordu içinde yetkin ve etkin olduğu görülmektedir. Bu işten sorumlu ne kadar görevlinin olduğu tam bilinmemekle birlikte her askeri birlik için birer çavuşun varlığı düşünülebilir.

Bozkır çevresinde askerlik ve ordu büyük önem taşıdığından kahramanlık ve savaşla ilgili birçok kavram oluşturulmuştur. Bu kavramlar askeri yapıyı anlamaya büyük ölçüde imkân sağlamaktadır. En sık kullanılan kavramlar arasında kahramanlıkla ilgili olanlar dikkati çekmektedir. Bu bağlamda "alp, alpagut, er, tonga, sökmen" gibi adlandırmalar vb. çok sayıda terim bozkır çevresinde kullanılıp karşılık bulmuştur.

Alp kelimesi eski ve yeni birçok Türk lehçesinde kahraman, cesur, yiğit, zorlu manalarına gelmektedir. Bu kelime şahıs adı olarak kullanıldığı gibi, bir sıfat, bir unvan ve boy teşkilatı içinde bir asalet zümresinin adı olarak da ortaya çıkmaktadır (Caferoğlu, 1968: 12). Türkçe sözlüklerde alp kelimesinin karşıllğı yiğit, kahraman, bahadır, cesur, zorlu şeklinde geçmektedir (Eren, vd, 1988: 58; Dilçin, 1983: 8; Aksoy vd,, 1995: 111; Gabain, 2000: 260; Orkun, 1987: 759). Bu kelimeden "alpagut, alpırkanmak, alpırkamak, alp yol" gibi kelimeler de türetilmiştir. Alpagut bir rütbedir. Alpırkanmak "yorulmadan ısrarla bir şey üzerinde çalışmak ve kahramanca davranmak" anlamına gelmektedir. Alpırkamak "kendisine yiğit süsü vermek, sebatla çalışmak" manasında kullanılmaktadır. Alp yol ise "tehlikeli, çetin yol" demektir (Caferoğlu, 1968: 12). Alperen ise, "yiğit, bahadır" anlamındadır. Alplık "kahramanlık" olup, alplık etmek ise, "cesaret göstermek" anlamına gelmektedir (Aksoy vd., 1995: 112).

Bu eski Türk kelimesi "alıp” şeklinde ve yine aynı manada olmak üzere Altay, Abakan, Kazak, Kırgız lehçelerinde hala yaşamakta ve has isim olarak kahramanlık hikayelerinde daima geçmektedir: Alıp Kargışa, Alıp Salay, Kuzgun Alıp, Alıp Soyan vb. (Köprülü, 1986: 379). Bu durumda "alp" kelimesi "alıp" şeklinde de bulunmakta ve geçmişte de aynı şekilde kullanılmış görünmektedir.

Alp kelimesi tek başına kullanıldığı gibi, diğer isimlerle de kullanılmaktadır. Bunlar arasında Alp Argun, Alp Arslan, Alp Arslan Böri Bars, Alp Arslan Kutlug, Alp Bilge Kağan, Alp Er Han, Alp Kutlug Külüg, Alp Küçlüg, Alp Laçin, Alp Saru, Alp Taş, Alp Tigin, Alp Turmış, Alp Yürek vb. sayılabilir (Sümer, 1999: II, 775). 
Alp kelimesi ile aynı anlama gelen bagatur ve sökmen kelimeleri de bulunmaktadır. Bagatur kelimesi "bahadır, kahraman" anlamındadır (Gabain, 2000: 266). Sökmen kelimesi de "yiğit, kahraman" anlamına gelmektedir (Kaşgarlı Mahmud, 1992: 266). Ancak bu kelimeler Türk kültür çevresinde tek başlarına ya da diğer kelimelerle birlikte "alp" kelimesi kadar yer almamışlardır. Alp kelimesinin tek başına ya da diğer isimlerle birlikte uzun zaman diliminde yoğun olarak kullanıldığı görülmektedir.

Er kelimesi de Türk kültür çevresinde uzun zaman diliminde yoğun olarak kullanılmıştır. Bu kelimenin sözlük anlamı "erkek, kahraman, yiğit, asker, nefer, işini iyi bilen, yetenekli, koca" olarak yer almaktadır (Eren vd, 1988: 460). Er kelimesiyle birlikte kelimeler de kullanılmaktadır. Bunlar arasında "er adam, er kardaş, er oğlan, er oğlu" vb. kelimeler sayılabilir. Er adam "erkek", er kardaş "erkek kardeş”, er oğlan "erkek çocuk", er oğlu "asılzade" anlamlarına gelmektedir (Dilçin, 1983: 84).

Er kelimesi Türk kültür çevresinde yoğun kullanım alanı bulmuştur. Tek başına kullanıldığı gibi, başka isimlerle de kullanılmıştır. Bunlar arasında Er Basgan, Er Beg, Er Boz, Er Doğan, Er Doğmuş, Er Guş, Er Oğl1, Er Sığın, Er Taş, Er Tigin, Er Tokuş ve Er Tuğrul gibi isimler sayılabilir (Sümer, 1999: II, 803).

Tonga kelimesi de Türk kültür çevresinde kullanılmıştır. Tonga "yiğit, kahraman, kuvvetli, şevketli" anlamlarına gelmektedir. Aynı zamanda rütbe ve unvan olarak da yer almaktadır. Bu kelimeden tongalık kelimesi de türetilmiş olup, bunun karş1lığ “güçlü, kuvvetli" şeklindedir (Caferoğlu, 1968: 246). Tonga bebüre verilen addır. Bebür kaplan cinsinden bir hayvan adıdır (Kaşgarlı Mahmud, 1992: III, 368). Kaplan ise, kedigillerden, enine siyah çizgili, koyu sarı postu olan, Asya'da yaşayan çevik ve yırtıcı bir hayvan olarak bilinmektedir (Eren, vd, 1988: 787). Gayet büyük ve kediye benzeyen bu hayvanın üstü yol yol tüylü olup, saldırdığı zaman derisindeki tüyleri kabarıp korkunç bir manzara oluşturmaktadır. Bundan arslan bile korkmaktadır (Devellioğlu, 2004: 75). Derisinden kürk yapılmaktadır. Savaş zamanında kahramanlar onun derisini giyerler. Bu kıyafet kimin üzerinde olursa, o kimse suya gark olmaz, ateșe batmaz, hiçbir savaș silahı ona etki etmez. Türkçe "böbür" adı da beber adından alınmıștır (Mütercim Asım Efendi, 2000: 54). Böbürlenme, böbürtü ve böbürlenmek kelimeleri de böbür'den türemiş olmalıdır (Eren, vd., 1988: 219).

Kaşgarlı Mahmud tonga kelimesinin Türkler arasında yaşadığına, ancak anlamının kaybolmuş olduğuna dikkat çekmektedir (Kaşgarlı Mahmud, 1992: III, 368). Gerçekten Türkler arasında eskiden beri kullanılan bu kelime çok yaygın olarak bulunmamaktadır. Bu çerçevede Türk kültür çevresinde Alp Er Tonga, Alp Kılıç Tonga (Sümer, 1999: II, 867), Tonga, Tonga Alp Er, Tonga Tigin ve Tonga Tonga adları yer almaktadır (Sümer, 1999: II, 867).

Tonga yazılı kaynakların dışında arkeolojik buluntu olarak da görülmektedir. Arkeolojik kazılar sonucunda açılan kurganlardan tonga tasvirleri çıkartılmıştır. Bunun en güzel örneğini Kazakistan'da açılan Esik kurganından çıkartılmış olan ve "altın elbiseli adam" olarak bilinen kahramanın elbisesi üzerindeki tonga tasviri göstermektedir. Kahramanın elbisesinin göğüs hizasında tonga türü bir hayvanın başı tasvir edilmiştir. Bu hayvan kanatlı bir şekilde tasvir edilmek suretiyle kendisine tabiatüstü bir özellik verilmiştir (Esin, 1985: 142). Esik kurganı ve buluntularının İskit/Saka dönemine ait olması ve tonga tasvirinin bir kahramanlık alameti olarak yer alması dikkat çekmektedir. Ayrıca yazılı kaynakları desteklemek bakımından da tonga tasviri önemlidir.

Türk kültür çevresinde Alp Er Tonga adına çok fazla rastlanılmamaktadır. Bu isim bir tek kişiyi ifade etmektedir. Alp ve Tonga isimleri ile diğer isimler bir araya getirilerek Alp Kutlug Tonga Bilge Kılıç Tamgaç Hakan, Alp Kılıç Tonga Bilge Türk Tugrul Hakan isimleri de unvan olarak görülmektedir (Sümer, 1999: I, 119). Alp ve Er isimleri ile üçüncü bir isim bir araya getirilerek Alp Er Han, Alp Er Tays1 isimlerinin kullanıldığı da anlaşılmaktadır (Sümer, 1999: II, 775). Tonga ismine Tonga Alp Er dışında Tonga Tigin, Tonga Tonga ve Tonga Yürek isimlerinde de rastlanılmaktadır (Sümer, 1999: II, 866- 867).

Kaşgarlı Mahmud, tonga kelimesini açıklarken, "çok kere kişi adı olarak kullanıldığını, Tonga Han, Tonga Tigin" gibi adlar verildiğini belirtiyor. Bu açıklamadan sonra "Türklerin büyük Hakanı Afrasyab'ın asıl Türk adı Tonga Alp Er'dir. Bebür (kaplan) gibi kuvvetli, yiğit bir adam demektir" ifadesini kullanıyor (Kaşgarlı Mahmud, 1999: III, 368). Yusuf Has Hacib de Tonga Alp Er'e İranlıların Efrasiyab dediklerini belirtmektedir (Yusuf Has Hacib, 1988: 31). Türkler arasında Tonga Alp Er olarak bilinen ve İranlılarca Afrasyab olarak ismi geçen Türk hükümdarının İran kaynaklarında ismi Frangrasyan, Frasiyav, Urvad-gai-frast, Vidhirisa, Frasiyak, Vidharg-afrastaka ve Farasiyat şeklinde de geçmektedir (Duleba, 1995: 71). 
Büyük unvanlardan hareketle hanedan ve devlete de ad verildiği görülmektedir. Bu bağlamda arslan en önemli hükümdar unvanları arasında bulunmaktadır. Türk kültür çevresinde arslan ismi başta hükümdarlar olmak üzere devlet ileri gelenlerinin isimleri olarak devam etmiştir. Bu isim tek başına kullanıldığı gibi Ak Arslan, Alp Arslan, Gök Arslan, Kara Arslan, Kutlu Arslan vb. şekilde diğer isimlerle birlikte kullanılmıştır (Sümer, 1999: II, 771- 878).

Devlet ileri gelenleri tarafından kullanılan unvanlardan biri de böri, yani kurttur. Kurt, böri şekliyle Türk kültür çevresinde çeşitli Türk devletlerinde ad ya da unvan olarak da kullanılmıştır. Bu isim tek başına kullanılabildiği gibi başka isimlerle birlikte de kullanılmıştır. Özellikle Tiginler'de görülmektedir. Bu isim yalnızca böri şeklinde yer aldığı gibi Ak Böri, Al Böri, Böri Bars, Böri Tigin, Çocuk Böri Şenun, Gök Böri Kökey, İl Böri, Kök Böri vb. şekillerde de isim olarak geçmektedir (Sümer, 1999: II, 771- 878).

Bozkır çevresinde yırtıcı kuşların da unvan olarak kullanıldığı bilinmektedir. Bunlar arasında Toğrul, Toğan ve Çağrı adları ön plana çıkmaktadır. Kaşgarlı Mahmud, Toğrul, yani Tuğrul'un "bin kaz avlayıp, bunlardan ancak bir tanesini yediğini” belirtmektedir (Kaşgarlı Mahmud, 1992: IV, 632). Toğrul, yani Tuğrul adı tek başına kullanıldığı gibi başka adlarla birlikte de kullanılmıştır. Bunlar arasında, Adem Toğrul, Bsa Toğrul, Yap Toğrul, Kotan Toğrul, Edgü Toğrul vb. sayılabilir (Abdurrahman, 2004: 129). Aynı şekilde doğan ve çağrının da yırtıcılıkları ve avcılıkları ön plana çıkmaktadır. Doğan için Toğan Beğ, Toğan Tigin, Toğan Toğdu, Toğançuk; çağrı içinse Çağrı Bey, Çağrı Tigin ve Çağrı Subaşı vb. örnek gösterilebilir (Sümer, 1999: II, 792, 866).

\section{Teşkilat Yapısı}

Türklerin askeri teşkilatı sosyal yapısına uygunluk göstermektedir. Askeri teşkilatta emir- komuta zinciri içerisinde küçükten büyüğe ya da büyükten küçüğe doğru bir yapılanmanın olduğu dikkati çekmektedir. Bu hususta Asya Hunlarına dair kayda değer bilgiler bulunmaktadır. Devlet teşkilatının askeri teşkilat olarak yapılandığı anlaşılmaktadır: "Sırasıyla teşkilatı Sol ve Sağ Xian Wangları (Bilge Bey), Sol ve Sağ Da Jiangları (Büyük Generaller), Sol ve Sağ Danghu'lar ve Sol ve Sağ Gu Tu Hou'lar oluşturmuşlardır. Sol Tu-chi Wang (Sol Bilge Beyi) veliaht yaparlar" (Otkan, 2018: 24).

Bu hususta şu bilgilere de yer verilmektedir: "Sol ve Sağ Xian Wanglardan itibaren Dang Hulara değin konumu büyük olanlar 10 bin atlıya, küçük olanları birkaç bin atlıya sahiptir. 24 beyleri bulunmaktadır. Bu beylerin her biri Wan Qi= Tümen, yani 10 bin atlı unvanını taşımaktadır. Devlet büyüklerinin görevleri hep babadan oğla geçer. Sol taraf beyleri ve generalleri doğuda oturur. Sağ taraftaki beyler ve generaller batıda oturur. Sol ve Sağ Xian Wanglıklar ile Sol ve Sağ Lu-li Wanglıklar en büyükleridir. Sol ve Sağ Gu Tu Hoular devlet yönetimine yardımcı olurlar. Bütün bu 24 yöneticinin her biri binbaşı, yüzbaşı, onbaşı gibi yönetim kademeleri, küçük beylikler, başyardımcı, Du-wei, Dang Hu, Jü Qü gibi memurluklar oluşturmuşlardır” (Otkan, 2018: 25- 26).

Bu bilgilerden anlaşıldığı üzere Türk devletlerinin ordularında belirli bir düzen vardı. Başka bir ifadeyle askeri yapılanma belirli bir düzene göre oluşturulmuştu. Eski Türklerin ordusunda en büyük askeri birlik 10 bin kişilik kuvvet idi. Bu birliğe" tümen" adı veriliyordu (Orkun, 1987: 172, 182, 273). Tümenler de 1000'li 100'lü ve 10'lu olmak üzere teşkilatlandırılmış ve başlarına ayrı ayrı kumandanlar tayin edilmişti. Böyle bir yapılanmada "Tümenbaşı", "Binbaşı", "Yüzbaşı," Onbaşı" olmak üzere kumandanlar görev yapmaktaydı. Bu sistem günümüz Türk askeri teşkilatlanmasına büyük ölçüde benzerlik gösteriyordu. Daha da önemlisi Türk askeri teşkilatlanmasına temel oluşturuyordu. Yukarıda belirtildiği üzere en küçük askeri birim 10 kişiden oluşuyordu. Bunun 10 katı 100'lü, 100'lünün 10 katı 1000'li, 1.000'linin 10 katı 10.000'li grupları oluşturuyordu. Burada bir alt grubun bir üst grup sayıca 10 katı idi.

Eski Türk ordusunda kağan ordunun başkumandanıydı. Ondan sonra kağanın oğulları ya da kardeşleri arasından seçilen iki küçük kağan ve dört alt kağan ( 2 Şad ve 2 Yabgu) bölümlere ayrılmış toprakların yönetiminde görevlendiriliyordu. Sağ ve sol Şadlar, aynı şekilde sağ ve sol Yabgular oluyordu. Devlet yönetiminde görev yapan bu önemli şahsiyetler ordunun bölümlerine kumanda ediyorlard1. Örneğin Mo-tschio Kağan komutasında oğlu küçük kağan olarak aşağı yukarı 40.000 kişiye ve her iki Şaddan hir biri 20.000 kişiye kumanda ediyordu (Liu Mu Tsai, 1958: I, 429). Bu bilgiden anlaşılacağı üzere bir şad 20.000 kişiye kumanda ettiği halde, küçük kağanın 40.000 kişiye kumanda etmesi yine yetki bakımından bir kademelenmeyi göstermektedir. Ayrıca, tümen 10.000 kişiden oluştuğuna göre, burada dört tümenden söz edilebilir. Bu bağlamda orduda çoğu zaman birden fazla tümenin olduğu anlaşılmaktadır. 
Eski Türk ordusunun zaman zaman sayısı 100.000'leri buluyordu. Örneğin Asya Hun ordusu, Çin ordusunu M.Ö. 203 yılında Pe-teng kalesi çevresinde 400 bin atlıdan oluşan ordusuyla kuşatmıştır. Bu kuşatma esnasında kuzeyde yağız atlılar, batıda ak atlılar, güneyde doru atlılar doğuda kır atlılar bulunuyordu (De Groot, 1921: I, 63). Atların dizilişleri Türklerde yönlerin renklerle temsiline uygunluk gösteriyordu. Çünkü eski Türklerde batı ak, doğu gök, kuzey siyah ve güney kırmızı renklerle sembolize ediliyordu (Pritsak, 1954: 377). $\mathrm{Bu}$ anlayışa uygun olarak atların bu renklere en yakın olanları belirtilen yönlere dizilmişti. Daha da önemlisi yön ve renklere göre dizilen atlar ve atlılar karışıklığı önlemek, uygulanacak taktikleri başarmak açısından da önem taşıyordu.

Ordu toplam 40 tümenden oluşuyordu. Demek ki dağınık boyların tek devlet çatısı altında toplandığı ve siyasi otoritenin kurulduğu dönemlerde Hun ordusunun sayıs1 40 tümeni, yani 400 bini buluyordu Askeri teşkilatlanma da bu sayı dikkate alınarak gerçekleştiriliyordu.

Türk ordusu büyük ölçüde atlı birliklerden oluşuyordu. Bunlar zırhlı süvariydiler. Uzun mesafe silahları, yay ve ok, kısa mesafe silahları kılıç ve kargıydı (De Groot, 1921: I, 3). Askeri birlikler içerisinde bazen "yaya birlikleri” de bulunuyordu. Örneğin El- Teriş Kağan'ın komuta ettiği ordunun üçte ikisi atll, üçte biri ise yaya idi (Bilge Tonyukuk Yazıt1, I, bat1, 4).

\section{Süvari Birlikleri}

Eski Türk kavimlerinde farklı amaçlara hizmet eden askeri birlikler vardı. Şüphesiz bunlar arasında süvari birlikleri ilk sırayı alıyordu. Dolayısıyla at ve süvari ile ilgili birçok kavram ortaya çıkmıştır. Atlıg veya atlı̆̆ kavram olarak "atlı, sipahi, süvari" anlamına kullanılıyordu (Caferoğlu, 1968: 25). Atlu "atlı", atlu asker ise "atlı kişi, süvari" anlamında idi (Grönbech, 1992: 15). Ulaga kavram olarak "savaş atı" idi (Kaşgarlı Mahmud, 1992: III, 172). Yügürgen at ise "koşucu, yüğrük at" anlamındaydı (Kaşgarlı Mahmud, 1992: III, 54). Tutgak "geceleyin düşmanın gözcülerini ve ileri karakollarını yakalamak için çıkarılan atlı bölük" olarak biliniyordu (Kaşgarlı Mahmud, 1992: I, 467).

Türk kültür çevresinde herkes asker durumundaydı. Küçük yaştan itibaren silah kullanılması öğreniliyordu. Bunun için de barış zamanlarında ava gidiliyor ve av hayvanları avlanıyordu. Bu çevrede askerlik geçici değil, daimî idi. Buda yaşadıkları bölgenin coğrafi şartları dolayısıyla hayatlarını sürdürebilmek için kadın erkek çalışmak zorunda kalmalarından ileri geliyordu. Böyle bir çevrede bütün fertlerin ata binmeyi, ok atmayı öğrenmeleri yanında, günlük hayattaki devamlı çalışması kendilerini dayanıklılığa, cesarete ve zindeliğe de alıştırıyor ve güven hissi veriyordu. Çünkü bozkır çevresinde günlük normal hayatla askeri hayat arasında bir fark bulunmuyordu (Donuk, 1991: 456). Geleceğin savaşçısı daha çocuk yaşında talimlere başliyor, koyun sırtında biniciliği deniyor, yay ve ok ile önce bıldırcın ve fare, sonra tilki ve tavşan avlıyordu. Gençlik çağlarında çok sağlam, güçlü ve çevik oluyordu (Çakan, 2006: 171).

Atlı kavimlerin saldırılarına hiçbir ordu dayanamıyordu. Türk, vahşi hayvana, kuşa, havadaki hedefe, insana, çömeltilmiş veya yere konmuş hayvandan hedeflere, avının üzerine pike yapan kuşlara ok atıyordu. O, hayvanını hızla sürdüğü halde, öne, arkaya, sağa ve sola, yukarıya ve aşağıya ok atabiliyordu. Onun ikisi yüzünde, ikisi kafasının arkasında olmak üzere adeta dört gözü vardı. O, arkasındaki insana önündeki insan gibi okunu isabet ettiriyordu. Türkler süvarilerine iki, üç yay ve bu kadar da kiriş taşımayı öğretmişlerdi. Türk hücum ettiği zaman şahsı, silahı, hayvanı, hayvanının takımları ile ilgili her şeyi yanında bulunduruyordu. Hızlı yürüyüşe, devamlı yolculuğa, uzun gece yürüyüşlerine ve memleketler kat etmeye gelince bu hususta o cidden çok başarılıydı. Türk bir baytardan daha usta, atını istediği gibi terbiye etme bakımından seyislerden daha başarılıydı. Atını kendisi yetiştirir, tay iken kendisi terbiye ederdi. Atının adını söylerse atı onu takip eder, koşarsa atı arkasından koşardı. Onun atı üzerinde geçen günleri yer üzerinde oturarak geçirdiği günlerden daha çoktu. Altındaki hayvanı dinlendirmek istediğinde yere inmeden diğerine binerdi. Türk hem çoban, hem seyis, hem canbaz, hem baytar, hem süvariydi (El- Cahiz, 1988: 67- 68).

Türkleri haşin iklim şartları ve hayatın ağırlığı süratle yer değiştirmeye zorlamış ve çevikliği dolayısıyla at, onların varlıklarının kaçınılamaz bir faktörü halini almıştır. Onlar sonsuz bozkır düzlüklerinde ata binme sanatında mükemmel bir dereceye ulaşmak ve bu sanatın bütün inceliklerini öğrenmek firsatını bulmuşlardır. Bu insanların, sadece sert hayat şartlarına karşı mücadele etmeleri ile iş bitmemiş, aynı zamanda yabancılarla da savaşmak zorunda kalmışlardır. Kabileler en iyi otlaklara yahut en çok balığı bulunan bir ırmağa sahip olabilmek için birbirleriyle çetin bir mücadele içinde bulunurlar. Bu insanların silah yolu ile rakiplerini alt edebilmek ve günlük geçimlerini sağlayabilmek maksadıyla enerjilerinin en mühim kısmını bu savaşlarda 
kaybettikleri görülür. Ata binecek ve yay kullanılacak bir çağa geldikten sonra çocuğun savaşa hazırlanmasına başlanmıştır. Aralıksız devam eden savaşlar, en iyi okul hizmetini görmüş ve böyle bir askeri eğitim ile bunun devamlı talimleri, Türklerin savaş kabiliyetlerini mükemmelliğe ulaştırabilmiştir (Baştav, 1964: 40).

Mücadelelerinde uzun mesafe savaşları için en uygun silah vasfını kazanan yayı, dörtnala ilerleyen atlılar dahi maharetle kullanabilirlerdi. Atlılara savaşlarda uzaklara ulaşabilen bu silah önemli başarılar sağlamış, göğüs göğse savaşa yarayan kılıç ve mızrak gibi silahlara, atlılar fazla rağbet göstermemişlerdir. Bu sebeple atlı kavimler tarafından çok erkenden yay, asli silah olarak seçilmiş ve bunların icadı olan taktik de kendilerine diğer kavimler üzerinde bir üstünlük sağlamıştır. Bu taktiğin esası, hızla ilerleyen bir at üzerinde dahi, öne, arkaya, yanlara, aynı maharetle ok atmaktan ibaretti. Bu keyfiyet onları, savaşta karşılarına çıkacak yeni bir duruma derhal intibaka müsait kılıyor ve düşmanlarını beklenmedik emrivakiler karşısında bırakabiliyordu. $\mathrm{Bu}$ taktik ordulara, iki esaslı prensip bahşetmekte idi. Bunlardan birisi, düşmana orduları hakkında bir fikir edinmek ve kumandanın niyetlerini anlamamak imkânını vermemesi idi; bu hal onları gizliyordu. Diğeri ise, savaş anında istedikleri yere hızla ulaşabilmeleriydi. Savaşın ilk safı, çarpışma başlamadan önce aralarında uzaktan hissedilemeyecek mesafelerle birbirlerinden ayrılan masif ve devamlı bir cephe manzarasını arz ederdi. İkinci ve üçüncü safhaları ise, mümkün olduğu kadar araziye uydurularak düşmanın gözünden gizlerlerdi (Baştav, 1964: 40).

At süvarisini hiç tanımadığı diyarlara doğru götürüyordu. At üzerinde uzaktaki ülkeleri fethetmek mümkün oluyordu. Atlı kavimler taktiklerini hız ve hareket kabiliyeti üzerine oluşturuyordu. At üzerinde hızla giderken öne, arkaya ve yana aynı ehemmiyetle ok atabilmeleri sayesinde, yerleşik kavimlerin ağır hareket eden köylü orduları üzerinde aşılması mümkün olmayan bir üstünlük sağlıyorlardı. Düşman safları önünde şuraya buraya ok atıyor, saldırıyor ve sonra aniden geri çekiliyor ve ancak düşman saflarının yoğun savaş nizamını bozduktan sonra mücadeleye girişiyorlardı. İnsanların ürkek gözleri önünde bir firtına gibi görünüyor ve uçan kuş sürüleri gibi kayboluyorlardı. Atlıların en son zamana kadar başlıca silahı ok ve yaydı (Baştav, 1964: 45).

Süvarilerin giyimi hakkında ilk bilgilere kurganlardan çıkarılan giyim kalıntıları, maddi kültür unsurları ve kaya üzerindeki tasvirlerden öğrenebilmekteyiz. Bu çerçevede ortaya çıkartılmış kaya tasvirleri ile elbise ve kalıntıları önemli bir yer tutmaktadır. Arkeolojik kalıntı ve buluntulardan süvari giyim kuşamı hakkında bilgi sahibi olabiliyoruz. Darius'a ait kitabelerde Saka olarak adlandırılmış bir figür bulunmaktadır. Bu figür silahsız ve yerel giysilerle tasvir edilmiştir. Onun tek ayırt edici özelliği başlığı ve sakallı yüzüdür. Buradan ana hatlarıyla vücudu sıkıca saran ceket ve pantolon, püskülsüz yuvarlak tepeli başlık ve bağcıkla bileğe bağlanmış ayakkabı giydiği dikkati çekmektedir. Elbette bu giyim diğer toplumların giyimlerinden farklılık göstermektedir (Minns, 1913: 60).

Bu tür giyimin en güzel örneğini Kazakistan'da Alma-Ata yakınlarında Esik kurganından çıkartılmış olan ve kaynaklara "Altın elbiseli adam" olarak giren hükümdarın giyimi göstermektedir. Bu şahıs başında yüksekçe bir başlık taşımaktadır. Ancak bu başlık türünün daha da sivri olduğu bilinmektedir. Hatta Perslerin İskit topluluklarından bir grubu "Saka tigrakhauda" olarak tanımlamaları ok şeklinde sivri başlık giyen Sakalar olarak bilindiklerini göstermektedir. Arkeolojik boyutu ile de en önemli buluntu bu Esik buluntusudur. Ayrıca ceket, pantolon ve çizme rahat bir şekilde görülebilmektedir. Ceket adeta bir kocuk şeklinde olup, belde kalın bir kemer bu kocuk üzerinde bulunmaktadır (Akişev, 1978: 69).

Süvari giyimini arkeolojik kalıntı ve buluntular büyük ölçüde şekil bakımından aydınlatmaktadır. Bir halı, vazo ya da kaya üzerine yapılmış olan tasvirden ancak giyimin şekli hakkında bilgi sahibi olabilmekteyiz. Buradan başl1k, ceket, pantolon ve çizme hakkında görünüşlerinden hareketle bir hüküm verebilmek mümkün olabilmektedir. Diğer taraftan bu tür tasvirler malzeme türü hakkında bilgi sahibi olmamızı mümkün kılmamaktadır. Ancak kurganlardan çıkarılmış olan buluntu ve kalıntılar bozkır kavimlerinin ne tür malzemeden kıyafet yaptıklarını ya da hangi tür malzemeleri giyim için kullandıklarını söylememiz mümkün olabilmektedir. Eğer kürklü bir elbise parçası ortaya çıkarılmışsa, bunun hangi hayvanın kürkünden olabileceği, yün ya da tiftikten veyahut ipekten yapılmış olması türünün belirlenmesine imkân vermektedir. Ayrıca giyimin günlük hayatta kullanılan bir elbise mi ya da savaş esnasında $\mathrm{m}$ giyildiği anlaşılabilmektedir. Örneğin bir savaşçının giyimi görünüşü itibariyle günlük hayattakinden farklı olmamakla birlikte metal parçaları ağırlıklı elbiseler olarak ortaya çıkmaktadır. Kurgan buluntularına göre bir süvarinin zırhı ve teçhizatının ne kadar ağırlıkta olduğu da belirlenebilmektedir. Ayakkabı, pantolon, gömlek, miğfer ve kısa kılıçla 22- 23 kilogram geldiği ortaya konulmuş olmaktadır (Minzulin, 1991: 140-142). Şüphesiz savaş esnasında kullanılan giyim ağırlık bakımından 
da günlük hayatta kullanılandan farklılık göstermektedir. Savaş kıyafetinde de hangi malzemenin kullanıldığ1 tespitler esnasında bilinebilmektedir.

Bozkır kavimlerinin, özellikle Türklerin giyimi hakkında arkeolojik malzemeden başka yazılı kaynaklarda verilen bilgiler de önemli bir yer tutmaktadır. Şüphesiz arkeolojik malzemeye göre yazılı kaynaklardaki bilgiler daha geç dönemlere aittir. Ancak arkeolojik kalıntı ve buluntulardan elde edilenleri yazılı kaynaklardaki bilgiler desteklemektedir. Yazılı kaynak verilerine göre Türklerin giyimlerinin nasıl olduğu baştan ayağa kadar bilinmektedir. Bu kapsamda, börk, kaftan, şalvar ve çizme en önemli yeri tutmakta olup, kazılardan ortaya çıan buluntu verilerini açık bir biçimde desteklemektedir.

Türk giyiminde börk önemli bir yere sahipti. Börk imal etmek için kalıp kullanılıyordu. Kalıp ya kâğıttan yahut da çamurdan yapılıyordu. Kâğıt parçalara ayrılarak veya oyularak börk kalıbı haline getiriliyordu. Bu kalıplara göre malzeme kesilmek suretiyle börk üretiliyordu (Kaşgarlı Mahmud, 1992: III, 361). Börk yapımında özel aletler de kullanılıyordu. "Batga" adı verilen tahta üzerinde börk yapmak için keçe ya da yün kesiliyordu (Kaşgarlı Mahmud, 1992: I, 424). Çeşitli mesleklerde de olduğu gibi, börk dikiminde de imece usulü çalışılıyor ve yardım alınıyordu (Kaşgarlı Mahmud, 1992: II, 93). Normal büyüklükte börk olduğu gibi (Kaşgarlı Mahmud, 1992, IV, 108), uzun börk de yapılıyordu. Uzun börk için"sukarlaç börk" tabiri kullanılıyordu (Kaşgarlı Mahmud, 1992: I, 493). Önde ve arkada iki kanadı bulunan börk içinse "kuturma börk" adı kullanılıyordu (Kaşgarlı Mahmud, 1992: I, 490). Börk yapan ve satan kişiye "börkçi" deniliyordu (Kaşgarlı Mahmud, 1992: IV, 108).

Türklerin giyiminde kaftan özel bir yere sahipti. Kaftan gövde, yen (Kaşgarlı Mahmud, 1992: III, 109) ve etek olmak üzere üç parçadan oluşuyordu. Kaftanın gövde kısmı vücuda uygundu ve düğmelerle bele kadar ilikleniyordu. Kaftan kuşaklı oluyordu (Kaşgarlı Mahmud, 1992: III, 287, 298). Türkler kaftanın altına ve üstüne elbiseler giyiyorlardı. Onlar "yalma" (Kaşgarlı Mahmud, 1992: III, 34) adı verilen kalın kaftan ya da yağmurluk da giyiyorlardı. Türkler kaftanın altına çeşitli adlar taşıyan hırkalar, gömlekler vb. giyiyorlardı. Yenler kısa elbiseye "kulak ton" (Kaşgarlı Mahmud, 1992: I, 383) ve küçük hırkaya "çengşü" deniliyordu (Kaşgarlı Mahmud, 1992: I, 433). Bundan başka gömlek, "könğlek" adıyla biliniyordu (Kaşgarlı Mahmud, 1992: III, 383).

Elbise için "ton", "tonagu”, “tonangu”, “urbak" ve üst elbise, giyim, örtü anlamında da "yogurgan” tabiri kullanılıyordu (Caferoğlu, 1968: 246, 266, 301). Türkler elbise temizliğine de önem veriyordu. Uçta biten ve çövene benzeyen bir otla elbiselerini temizliyorlardı. Buna "şav" diyorlardı (Kaşgarlı Mahmud, 1992: III, 155).

Türklerin önemli giyeceklerinden biri şalvard. "Üm” kelimesi hem don, hem de üzerine giyilen şalvar ve pantolon için kullanılıyordu. Ayrıca şalvar için don ve pantolon anlamında "könçek" kelimesi de kullanılıyordu (Grönbech, 1992: 117). Bu farklı adlandırmalarda pantolonun malzemesi ön planda olmalıydı. Türkçe "kön", deri olduğuna göre, muhtemelen könçek deri pantolon olabilirdi. Çünkü diğer giyeceklerde olduğu gibi, pantolon da deri, pamuk, yün vb. malzemelerden olabilmekteydi.

Türklerin temel giyimlerinden biri de çizme ve ayakkabıydı. Türk çizmesi ya deriden ya da keçeden yapılıyordu. En iyi çizme yapılan deri sırt (sargı) kısmıydı (Kaşgarlı Mahmud, I, 1992: 152). Çizme için "etik" tabiri kullanılıyordu (Kaşgarlı Mahmud, 1992: III, 283). Bu tabir kısa çizme (Grönbech, 1992: 70), terlik ve ayakkabı anlamlarına da geliyordu (Caferoğlu, 1968: 78). Kesilen hayvanların derisinden yapılan Türk çarığına "izlik" deniliyordu (Kaşagrlı Mahmud, 1992: I, 104). Çizmeci ve ayakkabıcıya "etikçi”" deniliyordu (Grönbech, 1992: 70). Türkler ayaklarına "uçuk” dedikleri çorap da giyiyorlardı (Caferoğlu, 1968: 262).

\section{Yaya Birlikleri}

Bozkır çevresinde temelde iki tip askeri birlik vardı. Bunlardan biri -yukarıda üzerinde durduğumuz üzere- süvari birlikleriydi. İkinci grubu yaya birlikleri oluşturuyordu. Yadağ kelimesi kavram olarak "yaya, yayan" anlamında kullanılıyordu (Kaşgarlı Mahmud, 1992: III, 28). Bozkır çevresinde yaya birliklerine fazla ihtiyaç duyulmuyordu. Bu nedenle askeri birlikler arasında yaya oldukça azdı.

Yaya birliklerine ihtiyaç duyulduğunda yararlanılıyordu. Mesela İlteriş Kağan, 680 yılında istiklal mücadelesine başladığı zaman komuta ettiği ordunun üçte ikisi atlı, üçte biri ise yaya idi (Koca, 2010: 105). Buradan da anlaşılacağı üzere ordunun önemli bir kısmını süvari birlikleri oluşturuyordu. Zaten bozkırda yapılan mücadelelerde uzaktan savaş taktiği esas alındığından yaya birliklerine fazla ihtiyaç duyulmuyordu. 
Bozkır çevresinde savaş arazi hesaba katılarak gerçekleştiriliyordu. Düşman süvari birliklerinin etkin olacağı ovalara, vadilere doğru çekiliyor ve saldırı zamanı da ayarlanıyordu. Böylece düşman yenilgiye uğratıllyordu (Taşağıl, 2019: 149). Vadiler ve boğazlara çekilmiş düşmanı imha edebilmek için stratejik tepelere konuşlanmış yaya okçular da bulunuyordu. İstenilen yere çekilmiş olan düşmanı imha etmek için yayalar da ok atışına başlıyorlar ve büyük başarı sağlıyorlardı.

Bunun en güzel örneğini Tomris'in Kyros'a karşı mücadelesi gösteriyor. Tomris bu savaşta coğrafyayı çok iyi kullanmıştır. Tomris savaşırken Kyros'tan korkuyormuş gibi yaparak kendi birliklerince iyi bilinen dar geçide onu çekmeyi başarmıştır. Orada aniden karşısına çıkıp yerin doğasının da yardımıyla kesin bir zafer kazanmıştır (Frontinus, II, V, 5). Buna göre Massagetlerin Pers ordusunun önünü köprübaşına girişte kestikleri ve dağlık arazinin boğazında, yani Büyük Balhan'da onları zorladıkları ve yok ettiklerini anlamaktayız (Herrmann, 1930: 2128). Kyros'un Massagetler üzerine gerçekleştirdiği ve onun ölümüyle sonuçlanan bu savaş son araştırmalara göre, M.Ö. 528 yılında yapılmıştır (Togan, 1987: 33). Burada dar boğazda sıkıştırılan Pers askerleri üzerine boğazın iki yanındaki tepelerden yoğun ok atışları yapılmıştır. Bunları gerçekleştirenlerin yaya olarak konuşlandıkları anlaşılmaktadır. Buradan coğrafyanın verdiği imknlar ölçüsünde yayalardan yararlanıldığını söylemek mümkündür.

Yaya birlikleri yalnız savaşlarda değil, normal zamanlarda da görev yapıyorlardı. Sabit bir yerde korumaya ya da gözetlemeye ihtiyaç duyulduğunda yaya birliklerinden yararlanılıyordu. Ülkede emniyeti sağlamak ve ani baskınları önlemek için uygun yerlere erken haber almayı sağlayan, içinde daimî nöbetçilerin bulunduğu ateş kuleleri bulunuyordu. Bu kulelere kargu deniliyordu (Donuk, 1988: 99). Bu kuleler dağ tepelerine yapıliyor ve düşman geldiği zaman herkesin hazır bulunması için üzerinde ateş yakılıyordu (Kaşgarlı Mahmud, 1992: I, 426). Şüphesiz yakılan ateş sayesinde savaş hazırlığı için şartlar oluşuyordu. Kule üzerinde yanan ateş çok uzaklardan görülebiliyor ve buna göre hazırlık yapılıyordu. Bu kulede askerler yaya olarak görev yapıyorlardı.

Bu kuleler için "küzet" tabiri de kullanılıyordu. Kulelerde görev yapanlara ise gözetici, muhafiz anlamında "küzetçi" deniliyordu (Caferoğlu, 1968: 125). Söz konusu kuleler, ordunun bir bakıma ileri karakollarıydı. Stratejik açıdan önemli yerleri vardı. Kilometrelerce uzakta bulunan düşmanın hareket haberi çok kısa sürede devletin merkezine ulaşabiliyordu (Koca, 2010: 105). Modern araştırmalara göre böyle bir kule üzerinde yakılan ateşin dumaniyla haberleşme mesafesinin gündüz 170 kilometre olduğu uygulamalı çalışmalarla anlaşılabilmiştir (Taşağıl, 2019: 144). Bu mesafenin atlı düşman birliklerinin merkeze ulaşabilmesi açısından epey zamana ihtiyaç bulunuyordu. Bu bağlamda onlara karşı rahatlıkla önlem alınabiliyordu.

Yaya olarak görev yapanlar yalnız sınır karakollarında bulunmuyorlardı. Onlar ihtiyaç duyulan her yerde görev yapıyorlard1. Korunması gereken merkezlerde ve saraylarda nöbet tutuyorlardı. Böylece istenilen yeri korumak suretiyle güvenliği sağlıyorlardı. Gözleme ve muhafızlıkla uğraşanlara "karakçı" deniliyordu (Donuk, 1988: 99). Nöbetçinin ya da bekçinin kaleyi ve atı koruyabilmesi için uyanık olmasını emreden söze "sak- sak" deniliyordu. Bu kavram nöbetçi, muhafız anlamına da geliyordu (Kaşgarlı Mahmud, 1992: I, 333).

Yaya birlikleri süvari birliklerine nazaran çok az olmasına rağmen, ihtiyaç duyulan her yerde onlardan yararlanılıyordu. Onlar fazla hareket gerektirmeyen yerlerde görev yapıyorlardı. Savaş esnasında düşman dar boğazda ya da vadide sıkıştırılıp kuşatıldığında konuşlandıkları tepelerden ok atışları yapmak suretiyle büyük başarı sağlıyorlardı. Onların bu faaliyeti düşmana saldırı kapsamındaydı. Asıl sınırlarda bulunan kale ve kulelerde görev yaptıkları gibi devletin merkezinde stratejik öneme sahip yerleri korumakla da yükümlüydüler. $\mathrm{Bu}$ faaliyetleri ise savunma şeklinde idi. Dolayısıyla şartlar ve ihtiyaçlar yayaların hem saldırıda hem de savunmada görev yapacakları yerleri belirlemekteydi.

\section{Özel Birlikler}

Türklerin yaşadığı çevrede özel birlikler önemli bir yere sahipti. Büyük Türk devletlerinde hükümdarın yakın çevresinde özel birlikler bulunuyordu. Bunlar birinci derecede hükümdarın korunmasına dikkat ediyordu. Savaş esnasında hükümdarla birlikte savaşa giriyorlardı. Barış zamanında ise hükümdarın otağı ve sarayının korunmasından birinci derecede sorumlu idiler. Bozkırda bütün kahramanlar, yani savaşçı unsur eğitimli olmasına rağmen, özel askerler çok daha eğitimli ve savaş̧̧ı özelliklere sahipti.

Türk kültür çevresinde özel askerlerden oluşan bu birliklere özel adlandırmada yapıllyordu. Gök Türk döneminde kağanlarının bahadırlarından seçilmiş özel bir muhafız birliği bulunuyordu. Bu muhafız birliğinin askerleri ise böri= kurt adıyla anılmaktaydı (Koca, 2010: 102). Bunlar daimi savaş egzersizi karakterindeki spor 
hareketleri dolayısıyla zindeliği, çevikliği yanında savaşta yırtıcılığını koruyorlardı. Milli kaynaklarda Gök Türk askerleri hakkında şöyle denilmektedir: "Tanrı güç verdiği için babam kağanın askeri böri gibi, düşman koyun gibi imiş” (Bilge Kağan Yazıtı, doğu, 11). Yabancı kaynaklarda da Türk askeri aynı şekilde tanımlanmaktadır. Meşhur Tabgaç hükümdarı T'ai-wu'ya göre "Kurt sürüsünü andıran Türk ordusu karşısında Çin askeri taydan ve düveden farksızdı" (Kafesoğlu, 1989: 276). Bu açıklamalardan Gök Türk döneminde "Böri Birlikleri" bulunuyordu. Bunlar çeviklik, dayanıklılık, atılganlık, cesaret ve mücadele azminden dolayı "böri= kurt" olarak adlandırılmışlardı. Çünkü savaş sanatının bütün uygulamalarını biliyorlardı.

Bu şekilde tarih sahnesine çıkmış kahramanlardan biri Köl Tigin idi. Bilge Kağan'ın kardeşi ve devletinin direği olan Köl Tigin yiğitliği önünde durulmayan ve bahadırlığına karşı konulamayan Gök Türk kahramanıdır (Sümer, 1999: I, 49). O, ağabeyi ile Türk devletini güçlü, Türk milletini mutlu kılmak için hep mücadele etmiştir. Bilge Kağan, Köl Tigin yazıtında "Türk beyleri hücum ettiğini hep bilirsiniz" (Köl Tigin Yazıtı, doğu, 34) demek suretiyle Köl Tigin'in kahramanlığına dikkat çekmektedir. Gerçekten de Köl Tigin bir kahramandı. Adeta savaş için yaratılmıştı. Çin kaynaklarında "Köl Tigin savaş sanatının üstadıdır. Ona karşı gelmek kolay değildir" (Liu Mau Tsai, 1958: I, 175, 227) sözleri Köl Tigin'in büyük bir cengâver olduğunu ortaya koymaktadır. Köl Tigin yazıtında Köl Tigin'in kazandığı zaferlerden ve kahramanlıklarından söz edilmektedir. Onun insanüstü kahramanlıkları anlatılmaktadır. Onun "yaya olarak silahlı birini yakaladığı", at üzerinde mücadele esnasında "zırhından, kaftanından yüzden fazla ok ile vurdukları, yüzüne ve başına bir tanesini değdirmediği” belirtilmektedir (Köl Tigin Yazıtı, doğu, 32- 33). Şüphesiz Köl Tigin'in yakın çevresinde savaşan askerler de aynı kahramanlığı gösteriyor ve seçilmiş askerlerden oluşuyordu.

$\mathrm{Bu}$ şekilde oluşmuş birlikler için çeşitli tabirler kullanılıyordu. Muhafızlardan oluşan alaya "yortuk" deniliyordu (Kaşgarlı Mahmud, 1992: III, 42). Sarayı ve hükümdarı gündüz bekleyen muhafizlar ise "turğak" adıyla biliniyordu (Donuk, 1988: 105). Önce de belirttiğimiz üzere gözetleme ve muhafizlıkla uğraşanlara "karakçı" adı veriliyordu (Donuk, 1988: 99). Buradan bu özel birliklerin barış zamanlarında stratejik öneme sahip yerleri korudukları anlaşılıyor. Hükümdarı ve otağını koruyan bu muhafızlar özel birliklerden oluşuyordu. Dolayısıyla hep hükümdarın yakınında bulunuyorlardı. O, sabit bir yerde kaldığında onun koruyuculuğunu yapıyorlardı. Aynı şekilde bir yere gittiğinde de yakın çevresinde bulunuyorlardı. Savaşa katılması durumunda ise onun yanı başında mücadele ediyorlardı.

Özel birlikler hanedan ya da ya da hanedana yakın boylardan seçiliyordu. Çünkü Gök Türk döneminde Aşina ailesinden geldikleri için özel birliklere "Böri", Çince "Fu-li" deniliyordu (Taşağıl, 2019: 153). Bu birlikte görev yapan askerlerin kahraman olduğu kadar güvenilir olması da oldukça önemli idi. Çünkü hükümdar için her zaman ölmeyi göze alabilen kişiler olmaları gerekiyordu. Hükümdar için düşmana gözünü kırpmadan atılma özelliğine sahip olmalıydı. Sahip oldukları hem hanedan hem de çeviklik ve atılganlık özellikleriyle "böri= kurt" olarak belirtilen bu kişiler aynı zamanda birer "alpagut" idiler. Alpagut "tek başına düşmana saldıran, hiçbir yandan yakalanmayan yiğit" olarak biliniyordu (Kaşgarlı Mahmud, 1992: I, 144). Onlarda mücadele azmi tamdı. Düşmana hükümdarları ve inandıkları değerleri uğruna gözlerini kırpmadan saldiriyorlardi.

Özel birlikler askeri gösteri ve törenlere de katıllyorlardı. Başka ülkelerden elçi veya komutan düzeyinde kişiler geldiğinde, özel birlikler tam donanımlı olarak karşı tarafa güçlerinin yansıtılması amacıyla yürüyüşler gerçekleştiriyordu. Mesela M.Ö. 36 yılı civarında Kiçik Kutlug Alp Yabgu, Çinlilerle savaşa girmeden önce askerlerine böyle bir tören yaptırmıştı. 6. yüzyılın sonlarına doğru İşbara Kağan yanına gelen Çin elçisinin görmesi için birliklere geçit töreni icra ettirmişti. Tonga Yabgu'nun yanında misafir olarak kalan Hsüan Tsang'ın seyahat notlarında da bu tür törenlere rastlanılmaktadır. Bu notlarda Yabgu'nun etrafinda ipek sırmalı kaftanlar giymiş ve saçları bağlı 200 kadar subaydan söz edilmektedir. Onlar otağın önünde iki sıra halinde oturmuş olup, Yabgu'nun börileri, yani muhafız kıtası da tam arkasında bulunuyordu. Birliklerin geri kalanı ise develer ve atlar üzerine bindirilmiş, kürk ve ince dokuma giyinmiş, uzun mızraklar, bayraklar ve düz yaylar taşıyan süvarilerden oluşmuştu (Gömeç, 2019: 163). Bu bilgilerden anlaşılacağı üzere özel birlikler hükümdarların en yakın koruması durumunda idiler. Hükümdarın gerçekleştirdiği toplantılarda onu korumak için en yakınında konuşlanmışlardı. Bu bağlamda Türk ordularının çekirdeğini özel birlikler oluşturuyordu. Onların konumlarını bulundukları çevre belirliyordu. Savaşlarda at üzerinde hükümdarın çevresinde, barış zamanlarında da sabit bir yerde aynı şekilde hükümdarın çevresinde yerlerini alıyorlardı. 


\section{Keşif Birlikleri}

Türk çevresinde kayda değer işler yapan birliklerden biri keşif birlikleriydi. Keşif birlikleri süvarilerden oluşuyordu. Savaş zamanında düşman ordusunun durumunu öğrenmek için keşif kolu gönderiliyordu. Bu keşif koluna "yelme" deniliyordu (Donuk, 1988: 108). Yine askerin önde giden bölüğü içinde "yezek/yizek" tabiri kullanılıyordu (Kaşgarlı Mahmud, 1992: III, 18). Geceleyin düşmanın gözcülerini ve ileri karakollarını yakalamak için çıkarılan atlı bölüğe "tutgak" adı veriliyordu (Kaşgarlı Mahmud, 1992: I, 467). Düşmanın gece ordugâhını basan birliğe "akıncı" veya "basımcı" deniliyordu (Koca, 2010: 104). Buradan anlaşıldığı üzere keşif birlikleri gece baskınları da düzenliyorlardı.

Ele geçirilmesi planlanan ülkelerin önceden küçük birliklerle gözden geçirilmesi, bu memleket ne kadar uzak olursa olsun, ilk şart idi ve akıncılar vasıtası ile düzenlenen keşif mahiyetindeki seferler, bazen yıllarca sürerdi. Müspet sonuç alınan keşiflerden sonra yıpratma harektına girişilirdi. Küçük akıncı birliklerinden başka, daha kalabalık seri hareketli kuvvetlerce düşmanın yığınak merkezlerine, mühim yol kavşaklarına, yiyecek ve malzeme depolarına yöneltilen bu harekaâta, düşman takatsiz düşürülünceye kadar devam edilirdi. Keşif ve yıpratma seferleri sırasında, hasım tarafın moralini bozmak maksadı ile çeşitli korkunç ve inanılmaz rivayetlerin yayılması da ihmal edilmezdi (Kafesoğlu, 1989: 275).

Keşif seferlerinde fetih arzusu ve yeni vatan kurma fikri de önemli bir yer tutuyordu. Bozkırlarda bu arzu ve fikri gerçekleştirebilecek hayat tarzı mevcuttu. Bu hayat tarzı konar- göçerlik olup, vasıta ise attı. Bu hayat tarzı onlara cesaret, kuvvet ve büyük bir dinamizm kazandırmıştı. Onlar, atın sağladığı hız ve üstünlükle büyük ölçüde yeni imkânlara kavuşmuşlardı. At sayesinde çabuk bir biçimde geniş fetih hareketlerinde bulunabiliyorlardı (Koca, 2010: 40). Böylece onlar için yeni keşif hareketleri gerçekleştirilmiş oluyordu.

Keşif seferleri şartlara göre süvari birlikleri tarafından gerçekleştiriliyordu. Fethedilmek istenen ülkenin hayat tarzlarına uygun olup olmadığı, askeri gücü vb. birçok özellikler belirleniyordu. Bu bilgilerden sonra uzun ya da kısa vadeli çözümler üretilmek suretiyle uygulamaya konuluyordu.

\section{Sonuç}

Türk askeri yapısına askeri anlamda at ve demir güç katmıştır. Arkeolojik buluntulardan atlı kültürün Afanesyovo ve Andronovo kültürlerinden beslenmesi, zaman içerisinde binek hayvanı olarak kullanılmaya başlaması, konar-göçer hayat tarzı içinde önemli bir yer tutmuştur. Dikkate değer bir gelişme ise, Karasuk kültüründen başlamak üzere, demirin Türklerin hayatında önemli bir yerinin olmasıdır. Demirden büyük ölçüde faydalanılmış, özellikle hayatı devamlı mücadele içinde geçen Türkler kendi savaş gereçlerini bu dayanıklı madenden yapmışlardır. Eski Türk devletlerinin ortaya çıkışı ve kuruluşlarında büyük ölçüde "atın hızı ve demirin vurucu gücü” etkili olmuştur. Böylece kültür güç ve hız kazanmak suretiyle büyümeye başlamış ve geniş coğrafyalara yayılmıştır.

Türk devletlerinin ortaya çıkışında da bu iki temel unsur etkisini göstermiştir. Büyük Türk devletleri ortaya çıkıncaya kadar atın binek hayvanı olarak kullanımı ve demirden yapılan savaş gereçleri yaygınlık kazanmıştır. Türklerin bu bilgi ve birikimi tarihin derinliklerinden süzülerek gelmiş, onların sosyal, siyasî, kültürel, dinî ve ekonomik hayatına damgasını vurmuştur. Bu iki temel unsurdan büyük ölçüde faydalanan Türkler kısa zaman içerisinde dinamizm kazanarak geniş coğrafyalarda çeşitli topluluklara egemenliklerini kabul ettirmişlerdir.

Büyük Türk devletlerinin ortaya çıkışı M.Ö. 1200'lerden sonra olmuştur. Bu dönemde atın binek hayvanı olarak kullanımının yanında demirin de yoğun olarak kullanılmaya başlaması kültüre güç ve dinamizm kazandırdığından büyük Türk devletlerinin kuruluşu için uygun şartlar oluşmaya başlamıştır. Bu bağlamda kayda değer Türk devletlerinin temsilcileri olarak sırasıyla İskitler, Hunlar ve Gök Türklerden söz edilebilir. Bunlar büyük Türk devletlerini at üzerinde yay gerip ok atmak ve dağınık boyları bir devlet çatısı altında bir araya getirmek suretiyle kurabilmişlerdir.

Bozkır Türklerinde askeri kavram ve unvanlar oldukça çoktu. Çünkü toplum hayatı insanları kahraman olmaya zorluyordu. Askerlik ve ordu düzeni en sistemleşmiş toplumları Türkler oluşturuyordu. Bu bağlamda çok sayıda kavram kullanılıyordu. Bunlardan bir kısmı askeri teşkilatla bir kısmı ise teşkilat yapılanması dışındaki kavramlardı. Bunların bu denli çok oluşu bozkırda askerlik ve ordunun önemini ortaya koymaktadır.

Türk çevresinde sü= asker, ordu, urungu= savaşçı, çerĭg = asker, sübaşı= ordu komutanı," idi. Bu kelime “asker" karşıllı̆ıında kullanılıyordu. Bu kelime aynı zamanda "ordu” anlamında da kullanılıyordu. Uruş= savaş, 
mücadele, uruğ $=$ dövüş, süngüş $=$ savaş, muharebe, savaşta saldırma, yagıladaçı= mücahit, savaşkan, mücadeleci, savaşçı, akınçı= akıncı, geceleyin düşmanı basan asker, bası̆ $=$ gece baskını yapılacak olan ve ansızın düşmanın yakalanacağı yer, 1lgar/yılgar= baskın, hücum, akın, atlı hücum, dörtnala hücum anlamına geliyordu. Yezek/ yizek= asker öncüsü, yelme = izci, keşşa, öncül, yorçu= usta kılavuz, yirçi/yirtçi= rehber, kılavuz, yer gösteren, tıngçı= haberci, körüg= casus olarak biliniyordu. Yağı= düşman, kır-yağı= gizli düşman, tutgun/tutuğ= esir, tutsak, rehin anlamına geliyordu.

Türk çevresinde alp, sökmen gibi unvanlar da kullanılıyordu. Bu unvanlar yiğit anlamındaydı. Güçlü hayvan adları da unvanlar arasında önemli bir yere sahipti. Bunlar tonga= kaplan, arslan ve böri= kurt idi. Avc1 kuşların da unvan olarak kullanıldığı bilinmektedir. Bunlar arasında tuğrul= tavşancıl, doğan ve çağrı önemli bir yere sahipti. Kültür güce ve hıza dayandığından hızlı ve güçlü hayvan ve kuş adları unvan olarak kullanılıyordu.

Türklerde orduların üç temel özelliği vardı. Birincisi daimî idi. İkincisi askerler ücretli değildi. Üçüncüsü ise ağırlıklı olarak süvarilerden oluşuyordu. Bundan başka düzenli bir teşkilat yapısına sahipti. En azından Asya Hunlarında 10'lu sistem uygulanmıştı. Bu durum askeri yapılanmanın 10, 100, 1.000, 10.000 kişilik birliklerden oluşması şeklinde idi. Bu şekilde katlanarak giden bir teşkilat sistemi mevcuttu. Bir alt birlik bir üst birliğe bağlanmak suretiyle ordu oluşuyordu. Bu şekliyle Türk devletlerinin ordusu çok düzenli bir yapı oluşturuyordu. Böyle bir yapılanma dünyada Türklerin dışında başka milletlerde yoktu.

Ordu süvari birliklerinden oluştuğundan, süvarinin eğitimi ve giyimi büyük önem taşıyordu. Bir süvari başlık, ceket, pantolon ve çizme giyiyordu. Böylece atın üzerinde rahatlıkla hareket edebiliyordu. Aynı zamanda zırh olarak yapılmış kıyafetleri de böyle olup, hareketliliğini kısıtlamayacak şekilde yapılmıştı. Eski Türklerin bu giyim kuşamı günümüz modern toplumlarına da ilham kaynağı olmuştur.

Orduda süvari birliklerinden başka az sayıda yaya birlikleri de oluyordu. İhtiyaç olduğu yerde onlardan da yararlanılıyordu. Bundan başka özel amaca yönelik birlikler de oluşturulmuştu. Bunlardan birini keşif birlikleri oluşturuyordu. Diğeri ise özel birliklerdi. Özel birlikler hükümdarın yanında görev yapmakta idiler. Bunlar askerlerin en seçkin ve en kahramanlarından oluşuyordu.

\section{Kaynaklar}

ABDURRAHMAN, Varis, (2004). “Türklerin Ad Koyma Gelenekleri Üzerine Bir İnceleme”, Milli Folklor, Say1 61, 124- 139.

AKIŞEV, Kemal Alişar, (1978). Kurgan Issık, Iskustvo, Moskova.

AKSOY, Ömer Asım, vd., (1995). Tarama Sözlüğ̈̈, I, Türk Dil Kurumu Yayınları, İstanbul.

ARSLAN, Mahmut, (1984). Step İmparatorluklarında Sosyal ve Siyasî Yapı, İ.Ü. Edebiyat Fakültesi Yayınları, İstanbul.

BAŞTAV, Şerif, (1964). “Eski Türklerde Harp Taktiği”, Türk Kültürü, sayı 22, 39- 48.

CAFEROĞLU, Ahmet, (1968). Eski Uygur Türkçesi Sözlüğü, Türk Dil Kurumu Yayınları, İstanbul.

ÇAKAN, Varis, (2006). "Orhun Uygur Devleti Ordusu'nun Silahlanmasıve Eğitimi Üzerine Bir İnceleme", Türkiye Sosyal Araştırmalar Dergisi, Sayı 1- 2, Nisan- Ağustos, 165- 175.

DE GROOT, Johan Jacob Maria, (1921). Die Hunnen der vorchristlichen Zeit, I, Berlin, Walter de Gruyter, Berlin.

DEVELLİĞLU, Ferit, (2004). Osmanlıca- Türkçe Ansiklopedik Lugat, Aydın Kitabevi Yayınları, Ankara.

DİLÇìN, Cem, (1983). Yeni Tarama Sözlüğü, Türk Dil Kurumu Yayınları, Ankara.

DONUK, Abdülkadir, (1988). Eski Türk Devletlerinde İdarî- Askerî Unvan ve Terimler, Türk Dünyası Araştırmaları Vakfı, İstanbul.

DONUK, Abdülkadir, (1991). "Kuruluşunun 2200. Y11 Dönümünde Türk Ordusu”, Türk Kültürï,, Sayı 340, 455- 467.

DULEBA, Wladyslaw, (1995). The Cyrus Legend in the Sahname, The Enigma Pres, Krakow. 
EL- CAHİZ, (1988). Hilafet Ordusunun Menkıbeleri ve Türklerin Faziletleri, çev. Ramazan Şeşen, TKAE Yayınları, Ankara.

EREN, Hasan- vd., (1988). Türkçe Sözlük, I- II, Türk Dil Kurumu Yayınları, Ankara.

ESIN, Emel, (1985). “Kotuz: İkinci Köktürk Sülalesinin Tamgası”, Erdem, I/1, 125- 145.

FRONTINUS, Stratagems, (1997). Çev. Charles E. Bennett, The Loeb Classical Library, Cambridge.

GABAİN, Annamaria von, (2000). Eski Türkçenin Grameri, Çev. Mehmet Akalın,TDK Yayınları, Ankara.

GÖMEÇ, Saadettin Yağmur, (2019). "Kök Türkler ve Uygurlar Çağında Türk Ordusu Teşkilatına Umumî Bir Bakış”, Hunlar'dan Günümüze Türk Askeri Kültürï̈, Kronik Kitap, İstanbul, 159- 182.

GRÖNBECH, K., (1992). Kuman Lehçesi Sözlüğü, Çev. Kemal Aytaç, Ankara, Kültür Bakanlığı Yayınları. HERRMANN, Albert, (1930). "Massagetai”, Pauls Real Encyclopaedie der Classisschen Altertumswissenschaft, XIV/2, 2123- 2129.

KAFESOĞLU, İbrahim, (1989). Türk Milli Kültürüi, Boğaziçi Yayınları, İstanbul.

KAPLAN, Mehmet, (1955). “Türk Destanında Alp Tipi”, Zeki Velidi Togan'a Armağan, İstanbul, 204- 213.

KAŞGARLI MAHMUD, (1992). Divanü Lûgat-it Türk Tercümesi, I- IV, Çev. Besim Atalay, Türk Dil Kurumu Yayınları, Ankara.

KOCA, Salim, (1990). Türk Kültürünün Temelleri, I, Damla Neşriyat, İstanbul.

KOCA, Salim, (2002). “Türklerin Soy Kütüğ̈̈”, Türkler, 1. Cilt, Yeni Türkiye Yayınları, Ankara, 260- 265.

KOCA, Salim, (2010). Türk Kültürünün Temelleri, II, ODES Ltd Şti, Kültür Yayınları, Ankara.

KOPPERS, Wilhelm, (1941). "Etnolojiye Dayanan Cihan Tarihinin Işı̆̆ı Altında İlk Türklük ve İlk İndo Germenlik", Belleten, V/17- 18, 439- 480.

KÖPRÜLÜ, M. Fuad, (1986). “Alp”, İslam Ansiklopedisi, I, Milli Eğitim Basımevi, İstanbul, 379384.

LIU MAU-TSAİ, (1958). Die Chinesischen Nachrichten der Ost-Türken, I, Otto Harrassowitz, Wiesbaden.

MINNS, Ellis H., (1913). Scythians and Greeks, University Press, Cambridge.

MINZULIN, Aleksander I., (1991). "Skythische Rüstung im Experiment die Krigerbestattung von Gladkovscina”, Gold der Steppe, Archaeologie der Ukraine, Karl Wachholtz Verlag, Neumünster, 137- 142.

MUSTAFAYEV, Emir- SÇERBİNiN, Vladimir Georgiyeviç, (1989). Rusça- Türkçe Sözlük, Sosyal Yayınlar, İstanbul.

MÜTERCIM ASIM EFENDİ, (2000). Burhan-ı Katı, Haz. Mürsel Öztürk- Derya Örs, TDK Yayınları, Ankara.

ORKUN, Hüseyin Namık, (1987). Eski Türk Yazıtları, Türk Dil Kurumu Yayınları, Ankara.

OTKAN, Polat, (2018). Tarihçinin Kayıtlarına (Shi Ji) Göre Hunlar, Türkiye İş Bankası Kültür Yayınları, İstanbul.

ÖGEL, Bahaeddin, (1981). Büyük Hun İmparatorluğu Tarihi, I., Kültür Bakanlığı Yayınları, Ankara.

PRİTSAK, Omeljan, (1954). “Orientierung und Farbsymbolik”, Saeculum, V, 376- 383.

RASONYİ, Laszlo, (1993). Tarihte Türklük, Türk Kültürünü Araştırma Enstitüsü Yayınları, Ankara.

RUBEN, Walter, (1943). “Milattan Bin Sene Evvel Asya İçlerinden Muhaceret Eden Hindistan'ın En Eski Demircileri Arasında”, II. Türk Tarih Kongresi Zabıtları, Türk Tarih Kurumu Yayınları, İstanbul, 237- 242.

STEUERWALD, Karl, (1988). Almanca Türkçe Sözlük, ABC Tanıtım Basımevi, İstanbul.

STRABON, (1969). The Geography of Strabo, Çev. H. L. Jones, Harvard Universitiy Pres, Cambridge. 
SÜMER, Faruk, (1999). Türk Devletleri Tarihinde Şahıs Adları, I- II, Türk Dünyası Araştırmaları Vakfı, İstanbul.

TAŞAĞIL, Ahmet, (2019). “Türk Askeri Tarihinin Başlangıcı: Hun Ordusu”, Hunlardan Günümüze Türk Askeri Kültürü, Kronik Kitap, İstanbul.

TOGAN, A. Zeki Velidi, (1981). Umumî Türk Tarihine Giriş, I., İstanbul Üniversitesi Edebiyat Fakültesi Yayınları, İstanbul.

TOGAN, A. Zeki Velidi, (1987). “Sakalar (VI)”, Belgelerle Türk Tarihi Dergisi, Say1 23, 30- 34.

YUSUF HAS HACİB, (1988). Kutadgu Bilig, çev. Reşit Rahmeti Arat, Türk Tarih Kurumu Yayınları, Ankara.

ZVELEBİL, Marek, (1980). "Der Aufstieg der Nomaden in Zentralasien” Die Cambridge Enzyklopaedie der Archaeologie, 
